\title{
Üreticilerin Besi Sığırcılığı Desteklerinden Yararlanması Üzerine Etkili Faktörler
}

\section{Hasan Burak AĞIR (D), Cuma AKBAY(D)}

Kahramanmaraş Sütçü İmam Üniversitesi, Ziraat Fakültesi, Tarım Ekonomisi Bölümü, Kahramanmaraş,

$\bowtie$ : hburakagir@ksu.edu.tr

\section{ÖZET}

Türkiye hayvancılık faaliyetleri için gerekli koşullara sahip olmasına rağmen ulusal tarım politikasındaki tutarsızlıklar ile yaşanan teknik ve ekonomik sorunlar nedeniyle üretimde istenilen seviyede değildir. Sektörde kırmızı et üretiminde önemli bir rolü olan besi sığırcılığı işletmeleri serbest piyasa koşullarından olumsuz etkilenmekte ve üretimde istikrarsızlık yaşanmaktadır. Yaşanan bu istikrarsızlığı ortadan kaldırmak üzere çeşitli politika araçları kullanılmakta olup bunlardan en önemlisi hayvancılık destekleridir.

Araştırmanın amacı Doğu Akdeniz Bölgesinde besi sığırcılığının yoğun olarak yapıldığı Adana İlinde üreticilerin besilik erkek sığır desteğinden yararlanmalarında etkili olan faktörlerin belirlenmesidir. Araştırmanın materyalini 94 besi üreticisi ile yüz yüze yapılan anket çalışmasından elde edilen veriler oluşturmaktadır. Elde edilen sonuçlara göre işletmelerin destekten yararlanmalarında; eğitim durumu, hayvancılık deneyimi, işletme kaydı tutma ve teknik bilgi alma durumu, hayvan sayısı ve yem bitkileri yetiştirme durumunun etkili olduğu saptanmıştır.

Factors Affecting on the Producers' Utilization of Beef Cattle Support

\section{ABSTRACT}

Turkey has proper conditions for livestock production but due to the technical and economic problems and also inconsistencies in the agricultural policy, livestock production is not at the desired level. For these reasons, beef cattle farms are adversely affected by free market conditions and face instability in production. In order to reduce this instability, there are several alternative systems to improve the competitiveness and production. Livestock subsidies are one of the most important application of these systems.

The aim of this research was to determine the factors that effect on producers' utilization from the beef cattle support. The research was conducted in Adana province, located Eastern Mediterranean Region. The data obtained from face to face interviews with 94 producers. According to results; education status, farming experience, keeping records about farm, technical assistance, number of animals and forage crops cultivation factors were effective on farmers' utilization of beef cattle support.
DOI:10.18016/ksudobil.407625

\section{Makale Tarihçesi}

Geliş Tarihi : 30.01.2018

Kabul Tarihi : 06.04.2018

\author{
Anahtar Kelimeler \\ Besi sığırcılığı, \\ hayvancılık destekleri, \\ lojistik regresyon, \\ Adana
}

\section{Araştırma Makalesi}

To cite: Agır B, Akbay C 2018. Üreticilerin Besi Sığırcılığı Desteklerinden Yararlanması Üzerine Etkili Faktörler. KSÜ Tarım ve Doğa Derg 21(5): 738-744. DOI:10.18016/ksudobil.407625

\section{GíRIŞ}

Tarımsal üretim içinde hayvansal üretim ve bu üretim kolu içerisinde besicilik önemli bir rol üstlenmektedir. Besi sığırcılığı, süt sığırcılığının önemli bir çıktısı olan erkek danaların ekonomik açıdan değerlendirilerek yüksek verimli ve kaliteli ete dönüştürülmesinde bununla birlikte insanların sağlıklı ve dengeli beslenmelerinde de önemli görevleri bulunmaktadır (Aydın ve Sakarya, 2012).

2016 yllı verilerine göre dünyada 65 milyon ton gerçekleşen sığır eti üretimi toplam kırmızı et üretiminin \%33.82'sini oluşturmaktadır (FAO, 2018). Aynı dönemde Türkiye'de 3.9 milyon baş besi sığırından elde edilen toplam 1.06 milyon ton kırmızı 
et üretimi ile dünya sığır eti üretiminde \%1.61 pay almaktadır (TÜİK, 2018). 2017 yılı verilerine göre Türkiye'de 3.6 milyon baş sığırdan 987.5 bin ton kırmızı et elde edilmiş olup bu üretim miktarı toplam kırmızı et üretimi içinde yaklaşık \%88'lik paya denk gelmektedir (TÜİK, 2018).

Türkiye'de tarım sektörü içerisinde hayvancılık faaliyetleri istenilen seviyede olmasa da çeşitli tarımsal politika araçları ile desteklenmektedir. 1923 yılından günümüze hayvancılık destekleme politikaları her geçen yıl yeni düzenlemeler ve miktarındaki artışlar ile devam etmektedir (Demir, 2012). 2002 yılında toplam tarımsal destekler içinde hayvancılık desteklerinin payı \% 4.45 iken bu oran 2014 yılında \%28.59'a ulaşmıştır (Haygem, 2015). Gıda Tarım ve Hayvancılık Bakanlığı tarafından kırmızı et sektöründe uygulanan besilik erkek sığır desteklemesi doğrudan, besilik materyal üretim desteği, anaç sığır manda yetiştiriciliği, buzağı, anaç koyun keçi, sürü yönetimi istihdamı, çiğ süt üretim desteği ve yem bitkileri destekleri dolaylı olarak besiciliği etkilemektedir.

Literatürde konu ile ilgili çeşitli çalışmalar yapılmış olup bu çalışmalar daha çok bitkisel üretim ve süt sığırcılığında uygulanan destekler üzerine yoğunlaşmıştır. Konu ile ilgili yurtiçi literatür incelendiğinde besi sığırcıllı̆̆ tekniği ve ekonomisi (Saner ve Çukur, 2006; Köknaroğlu ve ark., 2006; Hazneci, 2007; Uğurtaş, 2008; Topcu ve ark, 2008; Gözener, 2013; Demirbaş ve Tosun, 2012; Can, 2015), hayvancılık desteklerinin değerlendirilmesi (Ertuğrul, 2000; Yavuz ve ark., 2009), süt siğırcılığı destekleri (Balaban ve Unakitan, 2006; Isık ve ark, 2009; Koçturk, 2009; Yılmaz, 2010; Aksoy ve ark., 2012), yem üretimi teşvikleri (Şahin ve Yılmaz, 2009) ve bitkisel üretim (Özüdoğru ve ark., 2015) üzerine araştırmalar olmasına rağmen besi sığırcılığı destekleri konusunda çalışmaya rastlanmamıştır.

Yabancı literatürde ise konu ile ilgili birçok çalışma mevcuttur ancak yapılan çalışmaların çoğunluğunu süt sığırcıllğında uygulanan desteklerin değerlendirilmesi şeklindedir. Skaggs ve Falk (1998) Güneydoğu Meksika'da refah analizi kullanılarak hayvan yemi desteklerinin piyasa ve üretici geliri üzerine olan etkilerini analiz etmişlerdir. Ben Arfa ve ark. (2015), Dries ve ark., (2014), Wolf ve Tonsor (2013), Kavoi ve ark. (2013), El Benni ve Finger (2013), Frahan ve ark. (2011), Sipilainen ve Kumbhakar (2010), Bezlepkina ve ark. (2005) araştırmalarında süt sığırcılığında uygulanan desteklerin işletmeler üzerine etkilerini ortaya koymuşlardır. Konu ile ilgili literatür değerlendirildiğinde yerli literatürde besi sı ̆̆ırcılığ işletmeleri teknik ve ekonomik yönden incelenmiş, yabancı literatürde ise yoğun olarak uygulanan desteklerin süt sığırcılığı üzerine etkileri incelenmiş olup besi sığırcılığı destekleri konusunda yeterli araştırma yapılmamıştır. Bu konuda yeterli araştırmanın olmaması ve bu araştırmanın önemli bir boşluğu dolduracak olması araştırmanın önemini ortaya koymaktadir.

Gerek hayvancılığın geliştirilmesi ve gerekse tarımsal üretim değeri içerisinde hayvancılığın payının arttırılması için sektörün desteklenmesi oldukça önemlidir. Bundan dolayı uygulanan bu politikaların etkinliğinin analiz edilmesi önem taşımaktadır. Araştırmada besi sığırcılığı işletmelerinin besilik erkek sığır desteğinden yararlanmalarında etkili olan faktörlerin belirlenmesi amaçlanmıştır.

\section{MATERYAL ve METOT}

Araştırmanın ana materyalini Adana ilinde besi sığırcılığ yapılan anketlerden elde edilen veriler oluşturmaktadır. Araştırmada anket yapılacak üretici sayısı Oransal Örnekleme Yöntemi ile belirlenmiştir (Newbold, 1995).

$$
n=\frac{N p(1-p)}{(N-1) \sigma_{p x}^{2}+p(1-p)}
$$

Formülde; $\mathrm{n}=$ Örnek hacmi, N= Toplam üretici sayısı, $\mathrm{p}=$ Besi sığırcılığı işletmelerinin oranı (maksimum örnek hacmine ulaşmak için 0.50 alınmıştır), $\sigma_{p x}^{2}=$ Varyansdır. Formüle göre $\% 95$ güven aralığı ve $\% 10$ hata payı esas alınarak örnek hacminin 94 olarak hesaplanmıştır.

Araştırmada üreticilerin sosyo demografik özelliklerinin belirlenmesinde tanımlayıcı istatistikler, besilik erkek sığır desteğinden yararlanan ve yararlanmayan işletmelerin çeşitli değişkenler itibariyle karşılaştırılmasında t-testi ve işletmelerin besi desteğinden yararlanma durumları ile çeşitli kesikli değişkenler arasındaki ilişkinin belirlenmesinde Ki-kare (Chi-square) testi kullanılmıştır. Besi sığırcılığı işletmelerinin besilik erkek sığır desteğinden yararlanmalarında etkili olan faktörlerin belirlenmesinde lojistik regresyon modeli kullanılmıştır. Bağımlı değişkenin ikili $(0,1)$ olabileceği durumlarda yaygın olarak kullanılan analiz yöntemleri Lojistik Regresyon (LR), Lojit, Probit ve Doğrusal Olasılık Modelleridir (Gujarati,1995). Modelde normallik varsayımı şartı aranmaması ve kolay yorumlanabilir olması modelin kullanımını artırmaktadır (Özdamar, 1999). Lojistik regresyon modeli temel olasılık oranına (Odds ratio) dayanır ve modelin parametreleri tahmin ederken en yüksek olabilirlik yöntemi kullanılmaktadır. Lojistik regresyon modeli (Savran ve ark., 2011);

$P(Y)=\frac{\exp \left(\beta_{0+} \beta_{1} X\right)}{1+\exp \left(\beta_{0+} \beta_{1} X\right)}$ 
şeklinde gösterilmektedir. Buradan modeldeki katsayılar hesaplanması ise aşağıdaki şekilde gösterilmektedir;

$\ln \frac{P(Y)}{1-P(Y)}=\beta_{0+} \beta_{1} X_{1}+\beta_{2} X_{2}+\cdots+\beta_{n} X_{n}$,

burada $\frac{P(Y)}{1-P(Y)}$ odds oranıdır.

Lojistik regresyon analizi ikili (binary), sıralı (ordinal) ve sınıflayıcı (nominal) olmak üzere üç şekilde uygulanmaktadır. Araştırmada bağımlı değişkenin (0 ve 1) ikili olmasından dolayı ikili (binary) lojistik regresyon modelinden yararlanılmıştır. Araştırmada modelde kullanılan bağımlı değişken desteklerden yararlanmayan üreticiler (0) ve desteklerden yararlanan üreticiler (1) şeklinde kodlanmıştır. Modele dahil edilen açıklayıcı değişkenlerin seçiminde üreticilerin desteklerden yararlanmalarında etkili olabileceği düşünülen değişkenler belirlenmiştir. Ayrıca konu ile ilgili araştırmalardan yararlanılmıştır (Akbay ve ark., 2015; Demir, 2009; Işık ve ark., 2009; Aşkan ve Dağdemir, 2015; Dionne ve Horowitz, 2016).

\section{BULGULAR ve TARTIŞMA}

Araştırma bölgesindeki üreticilerin sosyo demografik özellikleri Çizelge 1'de verilmiştir. Çizelgeye göre tüm üreticilerin ortalama yaşı 45.53 olarak hesaplanmıştır. Besilik erkek sığır desteğinden yararlanan ve yararlanmayan üreticilerin ortalama yaşlarının birbirine yakın olduğu tespit edilmiştir. Üreticilerin eğitim süreleri incelendiğinde destekten yararlanan üreticilerin yararlanmayanlara göre daha yüksek eğitim düzeyine sahip olduğu saptanmıştır. Çizelgeye göre eğitim süreleri destekten yararlanan üreticilerin 8.02, destekten yararlanmayan üreticilerin ise 6.11 ve işletmeler ortalamasında 7.24 yıldır. Yapılan t testi sonuçlarına göre işletmelerin destekten yararlanma durumu ile eğitim süresi ortalamaları arasındaki farklılık istatistiksel olarak anlamlı bulunmuştur $(p=0.001)$. Gözener (2013) yaptığı araştırmada işletmeler ortalamasında üretici eğitim süresini 6.68 yll olarak hesaplamıştır. Ege bölgesinde gerçekleştirilen araştırmada Demirbaş ve Tosun (2012) üretici eğitim süresini ortalama 6.90 yll olarak saptamıştır.

Üretici ailesinde ortalama 5.15 kiși bulunmakta ve bu kişilerden ortalama 2.30 kişinin tarımla uğraştığı sonucuna ulaşılmıştır. Hazneci (2007) Amasya ili Suluova ilçesinde ortalama aile birey sayısını 5.89 kişi olarak hesaplamıştır. Aile bireyleri içerisinde iki kişinin tarımla uğraştığı, diğer bireylerin ise tarım dışı işlere yöneldiği söylenebilir. $\mathrm{Bu}$ durum besi sığırcılı̆̆ faaliyetinin devamlılığı açısından bir dezavantajdır. $\mathrm{Bu}$ nedenle karar vericilerin tarımsal nüfusu kırsal alanda tutmaya yönelik teşvik ve verilen destekleri artırması önemli görülmektedir. Üreticilerin hayvancillk deneyiminin işletmeler ortalamasında 20.69 yıl olduğu saptanmıştır. Hayvancılık deneyimi destekten yararlanan üreticilerde 19.75 yararlanmayan işletmelerde ise 22.06 yıldır (Çizelge 1). Bağımsız iki örnek t testi sonuçlarına göre üreticilerin hayvancılık deneyim süreleri arasındaki farlılık anlamlı değildir $(\mathrm{p}=0.232)$.

Üreticilerin işletme kaydı tutma, besicilikten memnun olma, teknik bilgi alma ve destekleri yeterli bulma durumları Cizelge 2'de verilmiştir. Cizelgeye göre tüm üreticilerin \%45.74'ünün işletme kaydı tuttuğu saptanmıştır. Destekten yararlanan üreticilerde bu oran $\% 58.93$ olup desteklerden yararlanmayan üreticilerde ise \%26.32'dir. Üreticilerin işletmelere ait hayvan varlığı, canlı ağırlık artışı, bakım ve besleme konularında kayıt tuttukları belirlenmiştir. Üreticilerin desteklerden yararlanma durumu ile işletme kaydı tutma durumu arasında Ki-kare (Chi-square) analizi sonuçlarına göre anlamlı bir ilişki olduğu saptanmıştır $(\mathrm{p}=0.002)$. Üreticilerin besicilik faaliyetinden memnun olma durumları incelendiğinde tüm üreticilerin \%69.15’inin memnun olduğu sonucuna ulaşılmıştır. Besilik erkek sığır desteğinden yararlanan ve yararlanmayan üreticilerde de bu oranın yüksek olduğu saptanmıştır. Faaliyetten memnun olan üreticiler bu durumu uzun yıllardan beri besicilik yapmaları ve başka bir işle uğraşmanın mümkün olmamasından dolayı mecburi bir memnuniyet olması şeklinde dile getirmişlerdir. Besicilik faaliyetinden memnun olmayan üreticiler yem ve besilik materyal fiyatlarının yüksek olması ve satış aşamasında zorluklar yaşamalarının bu durumda etkili olduğunu belirtmişlerdir.

Çizelge 1. Üreticilerin sosyo-demografik özellikleri

\begin{tabular}{|c|c|c|c|c|c|c|}
\hline \multirow{2}{*}{} & \multicolumn{2}{|c|}{$\begin{array}{c}\text { Destekten } \\
\text { Yararlanmayanlar }\end{array}$} & \multicolumn{2}{l|}{ Destekten Yararlananlar } & \multicolumn{2}{c|}{ Tüm Üreticiler } \\
\cline { 2 - 7 } & $\bar{X}$ & $\sigma$ & $\bar{X}$ & $\sigma$ & $\bar{X}$ & $\sigma$ \\
\hline Yaş (Yıl) & 46.47 & 10.46 & 44.89 & 8.89 & 45.53 & 9.54 \\
\hline Ĕ̈itim süresi* (Yıl) & 6.11 & 2.14 & 8.02 & 3.20 & 7.24 & 2.97 \\
\hline Ailedeki birey sayısı (kişi) & 5.61 & 3.58 & 4.84 & 1.80 & 5.15 & 2.68 \\
\hline Tarımla uğraşan birey sayısı (kişi) & 2.58 & 2.86 & 2.11 & 1.37 & 2.30 & 2.09 \\
\hline Tarımsal deneyim (yıl) & 24.18 & 9.91 & 24.08 & 8.46 & 24.12 & 9.01 \\
\hline Hayvancılık deneyimi (yıl) & 22.06 & 9.26 & 19.75 & 8.95 & 20.69 & 9.10 \\
\hline
\end{tabular}


Çizelge 2. Üreticilerin işletme kaydı tutma, besicilikten memnun olma, teknik bilgi alma ve destekleri yeterli bulma durumları

\begin{tabular}{|l|l|l|l|l|l|l|}
\hline & \multicolumn{2}{|l|}{$\begin{array}{l}\text { Destekten } \\
\text { Yararlanmayanlar }\end{array}$} & \multicolumn{2}{l}{ Destekten Yararlananlar } & \multicolumn{2}{l|}{ Tüm üreticiler } \\
\hline İsletme kaydı tutma & $\mathrm{N}$ & \% & $\mathrm{N}$ & $\%$ & $\mathrm{~N}$ & $\%$ \\
\hline Hayır & 28 & 73.68 & 23 & 41.07 & 51 & 54.26 \\
\hline Evet & 10 & 26.32 & 33 & 58.93 & 43 & 45.74 \\
\hline Toplam & 38 & 100.00 & 56 & 100.00 & 94 & 100.00 \\
\hline Besicilikten memnun olma & & & & & & \\
\hline Hayır & 9 & 23.68 & 20 & 35.71 & 29 & 30.85 \\
\hline Evet & 29 & 76.32 & 36 & 64.29 & 65 & 69.15 \\
\hline Toplam & 38 & 100.00 & 56 & 100.00 & 94 & 100.00 \\
\hline Teknik bilgi alma & & & & & & \\
\hline Hayır & 4 & 10.53 & 1 & 1.79 & 5 & 5.32 \\
\hline Evet & 34 & 89.47 & 55 & 98.21 & 89 & 94.68 \\
\hline Toplam & 38 & 100.00 & 56 & 100.00 & 94 & 100.00 \\
\hline Destekleri yeterli bulma & & & & & & \\
\hline Hayır & 35 & 92.11 & 43 & 76.79 & 78 & 82.98 \\
\hline Evet & 3 & 7.89 & 13 & 23.21 & 16 & 17.02 \\
\hline Toplam & 38 & 100.00 & 56 & 100.00 & 94 & 100.00 \\
\hline
\end{tabular}

Araştırma bölgesindeki işletmelerin faaliyet tipi, bitkisel ürün ve yem bitkileri yetiştirme durumları Çizelge 3’te verilmiştir. Çizelgeye göre tüm işletmelerin \%64.96'sı kombine işletme iken \%34.04'ü yalnızca besi işletmeleridir. Kombine işletmeler desteklerden yararlanan ve yararlanmayan işletmelerde de daha fazladır. Ancak bu farklılık istatistiksel olarak anlamlı değildir ( $p=0.678)$. Ege bölgesinde gerçekleştirilen bir araştırmada Demirbaş ve Tosun (2012) tüm işletmeler içerisinde kombine işletmelerin oranının \%73.79, yalnız besi işletmelerinin oranının \%26.21 olduğunu saptamışlardır.

İşletmelerin \%52.13'ünde bitkisel ürün yetiştirilirken \%47.87'sinde yetiştirilmediği saptanmıştır. Destekten yararlanan işletmelerin \%58.93'ünde bitkisel üretim yapilmakta iken yararlanmayan işletmelerin \%42.11'inde yapılmaktadır (Çizelge 3). İşletmelerde yem bitkileri yetiştirme durumu incelendiğinde tüm işletmelerin yaklaşı \%60'ında yem bitkileri yetiştirilmediği saptanmıştır. Ki-kare analizine göre besilik erkek sığır desteğinden yararlanma durumu ile yem bitkileri yetiştirme durumu arasında istatistiksel olarak anlamlı bir farklılık olduğu saptanmıştır $(\mathrm{p}=0.062)$.

Üreticilerin besilik erkek siğır desteğinden yararlanmalarında etkili olan faktörlerin belirlenmesinde lojistik regresyon analizinden yararlanılmıştır. Öncelikle modele dahil edilen diğer bir ifade ile işletmelerin desteklerden yararlanmalarında etkili olabilecek faktörlere ait tanımlayıcı istatistikler verilmiştir. Çizelgeye göre bağımlı değişken besilik erkek sığır desteğinden yararlanma durumu, bağımsız değişkenler ise üretici yaşı, eğitim, hayvancılık deneyimi, işletme kaydı tutma, teknik bilgi alma, tarım dışı gelir, işletme tipi, hayvan sayısı ve yem bitkileri yetiştirme durumudur (Çizelge 4).

Araştırma bölgesinde besi sığırcılığ besilik erkek sığır desteğinden yararlanmalarında etkili olan faktörlerin belirlenmesine yönelik uygulanan lojistik regresyon analiz sonuçları Çizelge 5’te verilmiştir. Modelde kullanılan bağımsız değişkenlerin doğrulama oranı \%73.4 olarak hesaplanmıştır. Modelde dokuz değişkenin altısı istatistiksel olarak anlamlı bulunmuştur. $\mathrm{Bu}$ değişkenler eğitim, hayvancılık deneyimi, işletme kaydı, teknik bilgi alma durumu, hayvan sayısı ve yem bitkileri yetiştirme durumudur.

Eğitim durumunun istatistiksel olarak anlaml ve destekten yararlanma üzerinde pozitif bir etkisi olduğu saptanmıştır. Eğitim durumu lise ve üzeri olan üreticilerin diğer üreticilere göre besilik erkek sığır desteğinden yararlanma olasılığ 3.75 kat daha fazladır. Eğitim seviyesi arttıkça besilik erkek sığır desteğinden yararlanma olasılığ 1 da artmaktadır. Üreticilerin işletme ile ilgili kaylt tutma durumunun destekten yararlanma üzerinde pozitif bir etkisi olduğu belirlenmiştir. İşletme kaydı tutan üreticilerin destekten yararlanma olasılığ tutmayanlara göre 3.41 kat daha fazla olduğu saptanmıştır. Üreticilerin tarımsal yayım elemanlarından besicilik faaliyeti hakkında teknik bilgi alan üreticilerin almayanlara göre destekten yararlanma olasılığını 11.34 kat daha fazla olduğu tespit edilmiştir. Üreticilerin destekler konusunda yaşadıkları en büyük olumsuzluk konu hakkında bilgi eksikliğidir. Yayım elemanlarının üreticileri desteklerden yararlanma süreci hakkında bilgilendirmeleri üreticilerin desteklerden yararlanmalarında oldukça etkilidir. 
Çizelge 3. Besi işletmelerinin tipi, bitkisel ürün ve yem bitkileri yetiştirme durumu

\begin{tabular}{|l|l|l|l|l|l|l|}
\hline & \multicolumn{2}{|l|}{ Destekten Yararlanmayanlar } & \multicolumn{2}{l|}{ Destekten Yararlananlar } & \multicolumn{2}{l|}{ Tüm üreticiler } \\
\hline Işsletme tipi & $\mathrm{N}$ & $\%$ & $\mathrm{~N}$ & $\%$ & $\mathrm{~N}$ & $\%$ \\
\hline Kombine (süt ve besi) & 26 & 68.42 & 36 & 64.29 & 62 & 65.96 \\
\hline Yalnız besi & 12 & 31.58 & 20 & 35.71 & 32 & 34.04 \\
\hline Toplam & 38 & 100.00 & 56 & 100.00 & 94 & 100.00 \\
\hline Bitkisel ürün yetiştirme & & & & & & \\
\hline Hayır & 22 & 57.89 & 23 & 41.07 & 45 & 47.87 \\
\hline Evet & 16 & 42.11 & 33 & 58.93 & 49 & 52.13 \\
\hline Toplam & 38 & 100.00 & 56 & 100.00 & 94 & 100.00 \\
\hline Yem bitkileri yetiştirme & & & & & & \\
\hline Hayır & 27 & 71.05 & 29 & 51.79 & 56 & 59.57 \\
\hline Evet & 11 & 28.95 & 27 & 48.21 & 38 & 40.43 \\
\hline Toplam & 38 & 100.00 & 56 & 100.00 & 94 & 100.00 \\
\hline
\end{tabular}

Çizelge 4. Lojistik regresyon modelinde kullanılan değişkenlere ait istatistikler

\begin{tabular}{|l|l|l|}
\hline Değişkenler & $\bar{X}$ & $\sigma$ \\
\hline Bağımlı değişken & 0.60 & 0.49 \\
\hline $\begin{array}{l}\text { Besilik erkek sığır desteğinden yararlanma durumu } \\
\text { (0: yararlanmıyor, 1: yararlanıyor) }\end{array}$ & \multicolumn{2}{l|}{} \\
\hline Bağımsı değişkenler & 45.53 & 9.54 \\
\hline Üretici yaşı (yıl) & 0.26 & 0.44 \\
\hline Eğitim durumu (0:ilk ve ortaokul, 1:lise ve üzeri) & 20.69 & 9.10 \\
\hline Hayvancılık deneyimi (yıl) & 0.46 & 0.50 \\
\hline İşletme kaydı tutma durumu (0:tutmuyor, 1: tutuyor) & 0.95 & 0.22 \\
\hline Teknik bilgi alma durumu (0:hayır, 1: evet) & 0.26 & 0.43 \\
\hline Tarım dışı gelir (0: yok, 1: var) & 0.34 & 0.47 \\
\hline İşletme tipi (0: kombine, 1: yalnız besi) & 72.20 & 69.28 \\
\hline Hayvan sayısı (baş) & 0.40 & 0.49 \\
\hline Yem bitkileri yetiştirme durumu (0:hayır, 1:evet) &
\end{tabular}

Hayvan sayısının bir birim artması üreticilerin besilik erkek sığır desteğinden yararlanma olasılığını 1.01 kat artırmaktadır. Bununla birlikte yem bitkileri yetiştiren üreticilerin besilik erkek sığır desteğinden yararlanma olasilığ üreticilere göre 2.55 kat daha fazladır. Yem bitkileri desteklerinden yararlanmanın besilik erkek sığır desteğinden yararlanmayı artırdığını söylemek mümkündür.

Burada dikkati çeken bir husus üreticilerin hayvancılık deneyiminin besilik erkek sığır desteğinden yararlanma olasılığ etkisi olduğudur. Üreticilerin hayvancıllk deneyimin bir yıl artması destekten yararlanma olasılığını 0.93 kat azaltmaktadır. Deneyimli üreticiler süreç hakkında yeterince bilgi sahibi olmamaları ve sürecin uzun olmasindan dolayı desteklerden yararlanmak istemediklerini belirtmişlerdir. $\mathrm{Bu}$ nedenle tarımsal kuruluşlarda bulunan personelin üreticilere destekler konusunda bilgilendirme çalışmaları yapmaları oldukça önemlidir.

Akbay ve ark (2015) tarafindan yapılan araştırmada, süt sığırcılığı faaliyeti ile uğraşan üreticilerin uygulanan desteklerden yararlanmalarında eğitim, Damızlık Sığır Yetiştiricileri Birliğine üyelik, ahır tipi, soy kütügü tutma durumu, silaj yapma durumu ve işletmenin bulunduğu bölge faktörlerinin etkili olduğu belirlenmiştir. Demir (2009), Batı Marmara ve Kuzey Doğu Anadolu Bölgelerinde gerçekleştirdiği araştırmada üreticilerin hayvancılık desteklerinden yararlanmalarında etkili olan faktörlerin yaş, eğitim, tarım dışı faaliyette bulunma durumu, yem bitkileri üretim miktarı ve hayvan sayısı olduğunu tespit etmiştir. Işık ve ark., (2009), süt sığırcılığı işletmeleri ile gerçekleştirdikleri araştırmalarında üreticilerin tarımsal desteklerden faydalanmalarında eğitim durumu, hayvan ırkı, kaba yem kullanımının pozitif, işletme tipinin ise negatif etkisi olduğunu saptamışlardır. 
Çizelge 5. İşletmelerin besilik erkek sığır desteğinden yararlanmalarında etkili olan faktörler

\begin{tabular}{|l|l|l|l|l|}
\hline & Katsayı & Wald değeri & P değeri & Odds oranı \\
\hline Sabit & & & & \\
\hline Üretici yaşı & 0.021 & 0.439 & 0.508 & 1.021 \\
\hline Eğitim durumu & 1.320 & 3.106 & $0.078^{*}$ & 3.745 \\
\hline Hayvancılık deneyimi & -0.069 & 3.644 & $0.056^{*}$ & 0.934 \\
\hline İsletme kaydı tutma durumu & 1.229 & 4.179 & $0.041^{* *}$ & 3.418 \\
\hline Teknik bilgi alma durumu & 2.428 & 3.173 & $0.075^{*}$ & 11.342 \\
\hline Tarım dışı gelir & 0.136 & 0,044 & 0.834 & 1.146 \\
\hline İşletme tipi & 0.581 & 1.096 & 0.295 & 1.787 \\
\hline Hayvan sayısı & 0.010 & 3.082 & $0.079^{*}$ & 1.010 \\
\hline Yem bitkileri yetiştirme durumu & 0.934 & 2.766 & $0.096^{*}$ & 2.545 \\
\hline
\end{tabular}

${ }^{*} \mathrm{p}<0.10,{ }^{* *} \mathrm{p}<0.05$, Hosmer Lemeshow $\mathrm{p}=0.879$, Negelkerke $\mathrm{R}^{2}=0.366$

\section{SONUÇ}

Besi sığırcılığı gerek aile ve gerekse ülke ekonomisine önemli katkılar sağlayan stratejik bir üretim faaliyetidir. Besi sığırcllı̆̆ı faaliyeti yıllar itibariyle çeşitli politika araçları ile desteklenmiş ancak bu destekler tutarlılık sağlanamadığı için sonlandırılmıştır. $\mathrm{Bu}$ destekler içerisinde besilik erkek sığır desteği 2001 yılında uygulanmaya başlamış 2002 yılında son bulmuş ve 2011 yllinda tekrar uygulamaya konulmuştur (Resmi Gazete, 2001 ve 2011). 2011 ve 2012 yllında $300 \mathrm{TL} / \mathrm{baş} \mathrm{olan}$ besilik erkek sığır destekleme miktarı 2015 yılında 150 TL/baş, 2016 yllında 200 TL/baş olarak belirlenmiş olup, 2017 yllinda ise verilmemektedir.

Araştırma bölgesindeki işletmelerde ailedeki birey sayısının ortalama beş kişi olduğu ve yaklaşık iki kişinin tarımsal faaliyet ile uğraştığı tespit edilmiştir. Üreticiler ailedeki genç bireylerin tarımsal faaliyetle uğraşmak istemediklerinden dolayı başka işlerde çalıştığını belirtmişlerdir. Tarımsal faaliyetle uğraşan bireylerin az olması mevcut faaliyet kolunun devamlılığını olumsuz yönde etkilemektedir. $\mathrm{Bu}$ nedenle karar vericilerin genç bireyleri tarımsal faaliyete teşvik edecek politikalar belirlemeleri ve uygulamaları önemlidir.

Diğer önemli bir husus üreticilerin tecrübeli ancak eğitim seviyesinin düşük olduğudur. Karar vericilerin eğitim seviyesini yükseltemeyecekleri göz önüne alındığında en azından tarımsal yayım elemanları aracılığı ile üreticilere uğraştıkları faaliyet kolu hakkında daha verimli üretimi sağlamaya yönelik eğitim vermelerinin oldukça yararlı olacağı düşünülmektedir.

Üreticilerin yaklaşık \%83’ü besilik erkek sığır desteğinin yeterli olmadığını belirtmişlerdir. Burada üreticilere verilen bu desteğin ne kadarının üreticiye ulaştığının ortaya konulması oldukça önemlidir. Bu nedenle karar vericilerin verilen bu desteklemede meydana gelen kesinti miktarını göz önüne alarak destek miktarını belirlemesi önem arz etmektedir.

İşletmelerin besilik erkek sığır desteğinden yararlanmalarında etkili olan faktörler; üretici eğitim durumu, hayvancılık deneyimi, işletme ile ilgili kayıtları tutma durumu, teknik bilgi alma durumu, işletmedeki hayvan varlığı ve yem bitkileri yetiştirme durumudur. Burada hayvancılık deneyimi değişkeninin işletmelerin besilik erkek sığır desteğinden yararlanmalarında negatif yönlü etkisi varken diğer değişkenlerin pozitif yönlü etkisi olduğu saptanmıştır. Hayvancılık deneyimi arttıkça desteklerde yararlanma olasılığ azalmaktadır. Burada daha deneyimsiz ve yaş olarak daha genç olan bireylerin desteklerden yararlanmada daha istekli olduklarmı söylemek mümkündür.

Sonuç olarak besi sığırcıllı̆̆ ülke ekonomisine sağladığg katkılardan dolayı desteklenmesi gerekli olan bir hayvancılık koludur. Genel olarak üreticiler çeşitli kesintilerden dolayı mevcut desteklerin yetersiz olduğunu belirtmişlerdir. Bu nedenle karar vericilerin desteklerden yararlanan paydaşların görüşlerini alarak uygun bir destek miktarı belirlemeleri faaliyetin devamlılığı ve üreticilerin rekabet gücünün artırılması açısından oldukça önemlidir.

\section{TEŞEKKÜR}

Bu makale KSÜ Araştırma Projeleri Yönetim Birimince desteklenen 2016/5-76 M numaralı projeden türetilmiştir.

\section{KAYNAKLAR}

Akbay C, Bilgiç A, Şahin A, Tümer Eİ 2015. Türkiye'de Süt Sığırcılığında Uygulanan Desteklerin İşletme Karlılı̆̆ Üzerine Olan Etkileri. Tübitak Proje No: 1120824, 113 s.

Aksoy A, Terin M, Keskin A 2012. Türkiye Süt Sığırcıllğında Islah ve Destekleme Politikalarının Bölgesel Etkileri Üzerine Bir Araştırma. Atatürk Üniv. Ziraat Fak. Derg., 43(1): 59-64.

Aşkan E, Dağdemir V 2015. Devlet Desteklemelerinden Faydalanan Süt Sığırcıllğ̆ı Yapan İşletmelerin Üretim Değerini Etkileyen Faktörlerin Analizi: Erzurum, Erzincan, Bayburt İlleri Örneği. Tarım Ekonomisi Dergisi, 21(2):69-76.

Aydın E, Sakarya E 2012. Kars ve Erzurum illeri Entansif Sığır Besi İşletmelerinin Ekonomik Analizi. Kafkas Üniversitesi Veteriner Fakültesi Dergisi, 18(6): 9971005.

Balaban A, Unakitan G 2006. Edirne Il'inde Süt Siğırcılı̆̆ını Üretim, Fiyat ve Pazarlama Politikalarmın Değerlendirilmesi. Trakya Üniversitesi Fen Bilimleri Enstitüsü, Yüksek Lisans Tezi, 50 s.

Ben Arfa N, Daniel K, Jacquet F, Karantininis K 2015. 
Agricultural Policies And Structural Change In French Dairy Farms: A Nonstationary Markov Model. Canadian Journal of Agricultural Economics. 63(1):1942.

Bezlepkina I, Oude L, Oskam AJ 2005. Effects of Subsidies In Russian Dairy Farming. Agricultural Economics. 33(3): 277-288.

Can MF 2015. Ankara İli Merkez İlçelerindeki Sı̆̆ır Besi İşletmelerinin Ekonomik Analizi. Eurasian Journal of Veterinary Sciences, 31(2): 87-94.

Demir N 2009. Destekleme Politikalarının Hayvancllı Sektörü Üzerine Etkilerinin Bölgesel Karşlaştırmalı Analizi. Atatürk Üniversitesi Fen Bilimleri Enstitüsü, Doktora Tezi, Erzurum, 143 s.

Demir N 2012. AB ve Türkiye'de Hayvancllık Politikalarındaki Son Gelişmelerin Uyum Süreci Açısından Karşılaştırılması. Alınteri, 23(B): 58-63.

Dionne K, Horowitz J, 2016. The Political Effects of Agricultural Subsidies in Africa: Evidence From Malawi. World Development, 87: 215-226.

Dries L, Gorton M, Urutyan V, White J 2014. Supply Chain Relationships, Supplier Support Programmes And Stimulating Investment: Evidence From The Armenian Dairy Sector. Supply Chain Management-An International Journal, 19(1): 98-107.

El Benni N, Finger R 2013. Gross Revenue Risk In Swiss Dairy Farming. Journal of Dairy Science. 96(2): 936-948.

Ertuğrul C 2000. Hayvancılık Sektöründe Destekleme Politikalarının Analizi ve Üretim Artışı Için Gerekli Önlemler. 2. Hayvancılık Kongresi-II (21-22 Kasım), Ankara.

FAO 2018. Food and Agriculture Organization. www.fao.org/faostat.

Frahan BH, Baudry A, Blander R, Polome P, Howitt R 2011. Dairy Farms Without Quotas In Belgium: Estimation And Simulation With A Flexible Cost Function. European Review of Agricultural Economics, 38(4): 469-495.

Gözener B 2013. TR83 Bölgesinde Sı̆̆ır Yetiştiriciliğine Yer Veren İşletmelerin Ekonomik Analizi ve Teknik Etkinlik. Gaziosmanpaşa Üniversitesi Fen Bilimleri Enstitüsü, Doktora Tezi, 157 s.

Haygem 2015. Hayvancılık Genel Müdürlüğü Kırmızı Et Stratejisi. Ankara.

Hazneci K 2007. Amasya İli Suluova İçesinde Sığır Besiciliği Yapan İşletmelerin Etkinlik Analizi. Ondokuz Mayıs Üniversitesi Fen Bilimleri Enstitüsü, Yüksek Lisans Tezi, $84 \mathrm{~s}$.

Isık, HB, Aksoy A, Yavuz F 2009. Factors Affecting Dairy Farmers' Utilization of Agricultural Supports In Erzurum. Scientific Research and Essay, 4(11): 12361242.

Kavoi MM, Haog DL, Pritchett J 2013. Influence of Institutional And Socio-Economic Factors on The Supply Response of Smallholder Dairy Farms In The Marginal Zones of Kenya. Journal of International Development, 25(3): 393-411.
Koçturk M 2009. A Case Study of Increasing Income of Dairy Cattle In Rural Area In Western Part Of Turkey. Journal of Animal and Veterinary Advances, 8(9): 16851688.

Köknaroğlu H, Yılmaz H, Demircan V 2006. Afyon İli Besi Sığırcılı̆̆ İşletmelerinde Kesif Yem Oranının Besi Performansı ve Karlılığa Etkisi. Süleyman Demirel Üniversitesi Ziraat Fakültesi Dergisi, 1(1):41-51.

Lu-rong R, Dan H 2014. A Study on the Effects of Fiscal Policy on Agricultural Production Management Intention and Behavior.

Newbold P 1995. Statistics for Business \& Economics, Fourth Edition, 1995, Prentice-Hall.

Özüdoğru T, Miran B, Taşkaya Top B, Uçum İ 2015. Pamuk, Ayçiçeği, Soya Üretiminde Fark Ödemesi Desteklerinin Etkisi. TEPGE YAYIN NO: 262. ISBN: 978-605-9175-34-0.

Saner G, Çukur F 2006. Ege Bölgesinde Sığır Eti Üretimi ve Pazarlaması Üzerine Bir Araştırma: İzmir İli Örneği. Tübitak, Proje no: TOGTAG-3052.

Savran F, Aktürk D, Dellal İ, Tatlıdil F, Dellal G, Pehlivan E 2011. Türkiye'de Seçilmiş Bazı İllerde Keçi Sütü ve Ürünleri Tüketimine Etkili Faktörler. Kafkas Üniversitesi Veteriner Fakültesi Dergisi, 17(2): 251-256.

Sipilainen T, Kumbhakar SC 2010. Effects of Direct Payments on Farm Performance: The Case of Dairy Farms In Northern Eu Countries. University of Helsinki, Department of Economics and Management Discussion Papers no: 43. Helsinki.

Skaggs RK, Falk CL 1998. Market and Welfare Effects of Livestock Feed Subsidies In Southeastern New Mexico. Journal of Agricultural and Resource Economics, 23(2): 545-557.

Şahin K, Yllmaz İH 2009. The Effects of Subsidizing Forage Production On Animal Production In Van, Turkey. Journal of Animal and Veterinary Advances, 8(3): 492495.

Topcu Y 2008. Süt Sığırcılı̆̆ı İşletmelerinde Başarıyı Etkileyen Faktörlerin Analizi: Erzurum நli Örneği. OMÜ Ziraat Fakültesi Dergisi, 23(1): 17-24.

TÜİK 2018. Türkiye İstatistik Kurumu. www.tuik.gov.tr.

Uğurtaş FT 2008. Konya İli Beyşehir İlçesi Doğanbey Beldesinde Besicilik Yapan İşletmelerin Ekonomik Analizi. Atatürk Üniversitesi Fen Bilimleri Enstitüsü, Yüksek Lisans Tezi, $75 \mathrm{~s}$.

Wolf CA, Tonsor GT 2013. Dairy Farmer Policy Preferences. Journal of Agricultural and Resource Economics, 38(2): 220-234.

Yavuz F, Işık HB, Demir N 2009. Destekleme Politikalarını Hayvancılık Sektörü Üzerine Etkilerinin Bölgesel Karşılaştırmalı Analizi. Tübitak Projesi, Proje no: 1080269.

Yılmaz H 2010. Süt Sığırcılığında Kooperatifler Aracılığıyla Desteklemenin Ekonomik ve Sosyal Etkileri: Adana İli Örneği. Çukurova Üniversitesi, Fen Bilimleri Enstitüsü, Doktora Tezi, 311 s. 